\title{
A HADIROKKANT OTTHONOK MAGYARORSZÁGI TÖRTÉNETE
}

\section{Szerzők:}

Fejes Zsolt (PhD)

Magyar Honvédség Egészségügyi Központ

Mihók Sándor (Dr. Jur.)

nyugalmazott jogtanácsos

Első szerző e-mail címe:

zsoltfejesdr@yahoo.com

\section{Lektorok:}

Mező Katalin (PhD)

Debreceni Egyetem

Mező Ferenc (PhD)

Eszterházy Károyl Egyetem

...és további két anonim lektor

\begin{abstract}
Absztrakt
Jelen tanulmányban a szerzők bemutatják a magyarországi hadirokkant otthonok történetét a kezdetektól a rendszerváltásig. A dolgozat áttekinti a hadigondozás (badirokekant otthon) rendszerének alapvetö funkecióit, beleértve a hasonlóságokat és különbségeket valamint felvázolja a korszak szociális ellátásának szerepét. A cikek hasznos lehet mindazok számára, akik - általános - áttekintést szeretnének kapni a hadirokekant otthonokról.
\end{abstract}

Kulcsszavak: hadigondozás, hadirokkant otthon

Diszciplínák: orvostörténet, katonaegészségügy

\section{Abstract \\ HISTORY OF THE DISABLED VETERANS HOME IN HUNGARY}

The authors of the recent study present and evaluate the characteristics of the disabled veterans home in Hungary from the beginning to the change of regime. This paper presents the basic functions of the military solicitude (disabled veterans home), including the similarities and differences and also outlines the prominent roles of social services. The article could be useful for all those who want to have a general overview of the disabled veterans' home.

Keywords: military solicitude, disabled veterans home

Disciplines: medical history, military health care

Fejes Zsolt és Mihók Sándor (2019): A hadirokkant otthonok magyarországi története. Lélektan és hadviselés - interdiszciplináris folyóirat, I. évf. 2019/1. szám. 59-72.

doi: $10.35404 /$ LH.2019.1.59 
Mielőtt - vázlatosan - áttekintenénk a hadirokkant otthonok magyarországi történetét, szükséges tisztáznunk, hogy kik is voltak a hadirokkantak, vagy, ahogy Európa szerte nevezték őket: az invalidusok. $\mathrm{Az}$ invalidus szó latin eredetű, jelentése: erőtlen, rokkant, szolgálatra képtelen katona. Az invalidusok háza pedig olyan menedékház, ahova a rokkant katonákat ingyen vették fel teljes ellátásra, sőt ha szükséges, gyógyításra is.

A rokkant katonák megbecsüléséről, gondozásáról már az ókortól vannak töredékes emlékeink, és Európa középkori történetének tanulmányozása során is találkozunk a sebesült és megrokkant katonákról való gondoskodással. Kontinensünkön azonban alig található írásos adat a lovagkort követő és katonailag ,zsoldos korszaknak" nevezett időből. A megmaradt források szerint a 13. században Fülöp Ágost francia uralkodó alapított először kórházszerű menhelyet, de ténylegesen csak 1576-ban jött létre Párizsban az ún. Maison de la Charité chrétienne. A 16. században a sebesülteket általában a katonai hadműveletek területén levő városi vagy egyházi ispotályokban hagyták, ellátásukért pénzt fizettek, de a sérült és rokkant katonák további sorsáról alig gondoskodtak. A rokkantaknak vagy özvegyeiknek egyszeri pénzsegélyt adtak, azonban a legtöbbjük koldusbotra jutott.

Fontos mérföldkő, hogy a modern nemzetállamok létrejötte (1648) óta az államok kizárólagos monopóliuma lett a háborúk viselése. Azonban az első generációs hadviselés korában a vonalban vagy oszlopban harcoló embertömegeket a tábori kórházak már nem tudták elég gyorsan követni. Ezért sok sebesült a harctéren - jórészt ellátatlanul - halt meg, nem jutott el a kórházig. A túlélő rokkant katonák sorsa pedig szinte kilátástalan volt. A harmincéves háború után a „feleslegessé vált" rokkantak valóságos csapást jelentettek Európára nézve: csapatokba verődve fosztogattak, raboltak és gyújtogattak. Ezért kerültek a Richelieu korabeli Franciaországban a súlyos sebesültek zár alá a Hospital de la Pitie-ben, a rokkantakat pedig kisegítő szolgálatra várakba vezényelték és Párizsból minden rokkant katonát kitiltottak. XIV. Lajos Saint-Germainben olyan invalidus házat épített, amelyben orvosok és sebészek gondozták a rokkantakat. Az angliai Chelsea városában1680ban a szárazföldi, Greenwichben a tengeri haderő rokkantjainak szerveztek gondozóintézetet. Oroszországban a cár 1682ben több monostort utasított rokkant katonák befogadására. Ausztriában a bécsi Allgemeine Krankenhaus épült a rokkantak gondozására, de a 18. század elején Bécsben, Prágában és Nyitrán is alapítottak katonai „rokkantházakat” (Mihók, 2018).

\section{Magyarországi \\ hadirokkant otthonok a}

\section{8. századtól a Nagy Háború végéig}

Hazánkban - európai mintára - már a 18. század első harmadában megjelentek a rokkant katonák, invalidusok elhelyezésé- 
re - és alapvetően nem gyógyítására szolgáló intézmények, amelyek alapítását nem az állam karolta fel, hanem elsősorban a rokkant alapok és a kegyes alapítványok adományaiból jöttek létre. A Pesti Invalidus Ház, a „hadastyánok pesti palotája" is ilyen nagylelkű adományokból épült fel. 1867-es osztrák-magyar kiegyezést követően a budapesti Külső-Soroksári úton magánadakozásból felépült a Pesti Honvéd Menház, amely csak az 1848/49. évi forradalom és szabadságharc agg katonáinak nyújtott kezdetben elhelyezést, az idő előrehaladtával pedig egészségügyi ellátást is.

A közös hadsereg (haditengerészet) és a m. kir. honvédség egyéneinek katonai ellátásáról szóló 1875. évi LI. törvénycikk alapján minden rokkant katona - tekintet nélkül rászorultságának és fogyatkozásának a fokára - rokkant-nyugdijban részesült, a sebesült ezen felül sérülési pótdíjat is kapott. A törvény rendelkezett ,a katonai rokkantak házainak ellátási állományába való fölvételről” is. Az Osztrák-Magyar Monarchia Bécsben, Pettauban, Prágában és Nagyszombaton tartott fenn katonai rokkantházakat, amelyek nem minősültek katonai gyógyintézeteknek. A ,boldog békeidők" idején az állami gondoskodáson kívül a kiszolgált katonák országszerte megalakították a helyi „hadastyán egyleteket", amelyek az ókori római katonai egyesületekhez hasonlóan, a kölcsönös segélyezést és tagjaik tisztességes eltemetésérôl való gondoskodást tűzték ki célul. A rokkant, munkaképtelen katonák gondozása ebben az időszakban - az elmúlt évszázadokhoz hasonlóan - a családi kötelék keretein belül zajlott. Azonban a Nagy Háború az emberi életekben, emberek testi épségében, köz- és magánjavakban már olyan nagyarányú pusztítás vitt végbe, hogy a háború áldozatairól és kárvallottairól intézményes gondoskodás vált szükségessé valamennyi hadviselő országban. Ezt az intézményes „istápolást és támogatást”, mely a hősi halottak családjára, a megrokkant katonákra és ezek családjaira is kiterjed, nevezzük hadigondozásnak (Pettkó-Szandtner, 1924).

A hadigondozás az akkori közigazgatási beosztás szerint a szociális igazgatás fogalomköréhez tartozott, múködése szerint három fontos részre volt osztható, mégpedig: a gyógyászati tevékenységre, a járadékszolgáltatásra, valamint a polgári életben való beilleszkedésre és a szociális támogatásra. A Rokkantügyi Hivatal vezetői felismerték, hogy a rokkantaknak már nem kizárólag az 1875. évi LI. törvénycikk alapján járó pénzbeli járandóságokra van szükségük, hanem egy egészen más és új ellátásra: tanácsokra, oktatásra, munkaeszközökre, emellett természetesen gyógyszerekre és állandó orvosi gondozásra is (Parádi, 1939).

Az 1916-ban indult „rokkantügyi akció” élharcosa Klebelsberg Kuno „A magyar rokkantügy szervezete" címú művében az alábbiak szerint foglalta össze a rokkantházak jövőjét (Klebelsberg, 1916):

„A gyógyithatatlan és munkaképtelen rokkantak számára az államnak kell megélhetésüket bižtositó rokekantsági nyugdíjat nyújtani, a tár- 
sadalmi áldozatkészségnek pedig egy másik szép célja, hogy otthonszerü kórházzá emelésével elviselhetövé tegye aroknak a rokkantaknak életét, akik késöbb is állandó orvosi felügyeletet igényelnek és kiknek nincsenek hozzátartoróik."

Elgondolkodtató, hogy ebben az időben a közös hadügyminiszter kezelésében múködő nagyszombati rokkantházon kívül más ilyen intézmény nem létezett. További hadirokkant otthon(ok) létrehozására a háború alatt egyáltalán nem került sor. A beteg és teljesen munkaképtelen rokkant katonák ellátását az állam társadalmi úton létesítendő menedékházak felállításával kívánta megoldani. Ezekben a menedékházakban a katonákat az államtól kapott évjáradék ellenében ápolták és gondozták volna.

A háborús viszonyok azonban nem tették lehetôvé ezek létrehozását, a társadalmi adakozáson és gyűjtésen túl semmilyen gyakorlati lépés sem történt a megvalósítás céljából. Ez alól egyetlen kivételt ismerünk, mely szerint az Országos Hadigondozó Hivatal és az Irgalom Háza 1917ben állami segély ellenében megállapodást kötött 14 gyógyíthatatlan rokkant katona befogadására. Ennek jelentősége az, hogy az Irgalom Háza nem volt kórház, mert nem gyógyítottak, csak ápoltak benne, és nem volt szegényház sem, holott betegei csak a szegénysorsúak közül kerülhettek ki. A ház célja és feladatai e két intézménytípus között helyezkedtek el. A gyógyíthatatlanok intézményes keretek között történő ápolása így méltán teszi az Irga- lom Házát a mai modern tanatológia és a magyar hospice házak elődjévé (Simon, 2012).

\section{Hadirokkant otthonok}

\section{a két világháború között}

Azok a világháború frontjain súlyosan megnyomorodott magyar katonák, akiket nem tudtak valamely intézetben elhelyezni és ezért hazakerültek, lényegében ki voltak szolgáltatva a környezetüknek és a háborút követő rossz körülmények miatt minden bizonnyal komoly terhet jelentettek a családtagjaik számára is. A tökéletes megoldás kellő számú férőhellyel ellátott rokkantotthon(ok) létrehozása lehetett volna. A kormányzat szerint:

„...azonban jóval nagyobb terhet jelent az államra a rokkeantházi ellátás, mint az a kelló mértékben felemelendō ellátási összeg, mely a rokkantnak családja körében való megélhetését biztositaná."

A feni idézet Pettkó-Szandtner Aladár M. Kir. Népjóléti és Munkaügyi helyettes államtitkár tollából származik, aki „A Magyar Hadigondozás" című művében fejtette ki a hadigondozásról és ennek keretén belül a hadirokkant otthonról vallott személyes, de egyúttal kormányzatinak is tekinthető álláspontját. A fentiekre tekintettel csak 1922. októberében hozták létre az egykori Laudon kaszárnyában a M. kir. Hadirokkant Otthont, mely 300 férőhelylyel nyitotta meg kapuit (PettkóSzandtner, 1924). 1924-től a hadirokkan- 
tak, hadiözvegyek és hadiárvák hadigondozási jellegű ellátásának szabályozása és felügyelete a Honvédelmi Minisztériumtól a Népjóléti Minisztérium hatáskörébe, maguknak az igényeknek a megállapítása pedig az állandó lakóhely szerint illetékes igénymegállapító bizottság hatáskörébe került. A hadigondozottak járadékszerű ellátásának szabályozásán és felügyeletén kívül a minisztérium hatáskörébe tartozott a hadigondozási intézményeknek: a budapesti M. kir. Hadirokkant-Otthonnak (IX., Timót-utca 3.), a M. kir. Tüdőbeteggyógyintézetnek (I., Németvölgyi-út 29.) központi felügyelete, személyzeti és dologi igazgatása.

A M. kir. Hadirokkant-Otthon a háborúban súlyosan (rendszerint legalább 75 százaléknyira) megrokkant, volt nem hivatásos állományú katonák végleges elhelyezésére szolgált, abban az esetben, ha megélhetésük a polgári életben nem volt biztosítható. Az intézet létszáma 1929-ben már meghaladta a 200 föt. A felvett hadirokkantak között nagy számban voltak hadivakok, továbbá teljesen mozgásképtelen, vagy mindkét lábra csonkított hadigondozottak is. Elme és tüdőbetegeket azonban az intézet szabályzata értelmében nem lehetett felvenni, valamint olyan hadirokkantakat sem, akiknek állapota kórházi kezeléssel még javítható volt. Az otthonba felvett hadirokkantak teljes ellátást (lakást, élelmezést, ruházatot, gyógyszerellátást stb.) kaptak, amivel szemben a beszüntetett rokkantsági járadék helyett csupán kisebb összegű, állandó segélyt kaptak. A hadirokkant-otthonhoz kosárfonó és ke- fekötő foglalkoztató műhelyek is tartoztak, amelyekben a hadirokkantak a „munkaórák" alatt dolgozhattak és munkájuk után „munkajutalmat” is kaptak. Az otthon gondozottjai közül a volt legénységi és altiszti állományú katonák közös kórtermekben, a volt tisztek pedig külön szobákban laknak. Az intézet rendelkezett rádióval is felszerelt társalgó-, olvasó- és dohányzóhelyiséggel, továbbá volt házikápolnája és általában minden olyan berendezése, amely a hadigondozottak otthonszerű ellátásához szükséges volt. Ezen kívül az otthon mellett működött egy elkülönített sebészeti osztály, amelyen különösen a hosszabb csontplasztikai kezeléssel gyógyítható hadirokkantak részesültek ideiglenes ellátásban. A kor kiváló sebésze és egyúttal az osztály vezetője Ertl János professzor és munkatársai több mint kétezer csontsérülést és sérüléses szövődményekben szenvedő beteget gyógykezeltek nagyrészt műtéti úton (Fekete, 1931).

A felvételre várakozó rokkant katonák jelentős száma azonban már halaszthatatlanná tette a Hadiotthon bővítését. Ezért Horthy Miklós kormányzó 1925. április hó 27-én kelt 693/K. I.-1925. számú „legmagasabb elhatározásával” hozzájárult az „1848/49-es Honvéd Menház”nak „M. kir. Rokkantházzá” történő átszervezéséhez. Az átszervezés augusztus hó 01-jei határidővel történt és az 1848/49-es aggharcosok jogai, felvételükre való igénye stb. változatlanul fennmaradtak. A m. kir. népjóléti és munkaügyi miniszter 1925. évi 104.723. számú rendelete részleteiben szabályozta az igényjogo- 
sultak „otthonszerű elhelyezését”. A teljesen elesett és otthon vagy család nélküli hadirokkantakról úgy kívánt a népjóléti kormány gondoskodni, hogy részükre egy olyan intézetet létesített, amelyben körülbelül 250-260 ,teljesen nyomorék hadirokkant" került elhelyezésre.

A Budapest, IX., Külső-Soroksári út 114. sz. alatti Rokkantház személyzetének rendszeresített állományában az igazgatón - és a 27 fôs személyzeten kívül - még két hámos ló (!) is helyet kapott. Az orvosi szolgálatot a rokkantház igazgatója és a hozzá beosztott orvos látta el. Az orvosi szolgálat kiterjedt a rokkantház állományába tartozó valamennyi beteg gyógykezelésére, az egészség ápolására, az egészségügyi teendők vezetésére, továbbá az elhelyezés, táplálkozás, testi tisztaság és az öltözködés felügyeletére, valamint az egészségügyi anyagról való gondoskodásra és ezekkel kapcsolatos írásbeli teendők ellátására. Az orvosok egyike a rokkantházban berendezett orvosi lakásban lakott. Az orvosok helyettesítése és pótlása iránt a népjóléti miniszter intézkedett. A vitéz nagybányai Horthy Miklós Úr Magyarország kormányzójává választása tizedik évfordulójának megörökítéséről szóló 1930. évi XI. törvénycikkben szerepelt két új hadirokkant otthon megépítésének terve is. A törvény általános indokolása szerint:

\section{„A Budapesten létesitendo" hadirokkant-otthon- nal a nemzet újabb jelét akarja adni bálájának és gondoskodásának derék fiaival szemben, akik a nagy háborúban a haza ezueréves határainak}

védelmében a harctereken testük és egéssségük épségét áldozták fel, és mint teljesen rokkantak, munkaképtelenné váltak. Végül a Szegeden létesitendö honvédrokekant-otthonnal a nemzet gondoskodni kiván azokról a derék honvédekról, akik nemes hivatásukban szolgálatuk teljesitése közben váltak munkaképtelenné."

Sajnos a nagy gazdasági világválság keresztülhúzta a kormányzat számításait, a két új hadirokkant otthon csak terv maradt.

1932. július 01-jei hatállyal a m. kir. Népjóléti és Munkaügyi Minisztériumtól a m. kir. Honvédelmi Minisztérium hadigondozási osztálya vette át - többek között - a hadirokkantak végleges rokkantházi elhelyezésének engedélyezését. A hadirokkantak és más hadigondozottak ellátásáról szóló 1933. évi VII. tc. (Hrt.) hatálya alá tartozó hadirokkantak rokkantotthoni elhelyezését a M. kir. Honvéd Rokkantház és Hadirokkantotthon telephelye (Budatest I. Németvölgyi-út 29.) látta el. Az intézeti gondozottaknak lakással, élelmezéssel, ruházattal és gyógyszerekkel ellátása, orvosi kezelése, valamint felügyelete, és a lelki szükségleteikről való gondoskodás tekintetében a honvédelmi miniszter által kiadott „,szervi határozványok” és a szolgálati utasítás rendelkezései voltak az irányadóak.

A megszűnt M. kir. Tüdőbeteggyógyintézet - korszerűtlen - baraképületeiben elhelyezett hadirokkantak elhelyezési körülményei azonban lényegesen rosszabbak voltak, mint amelyet a Timót utcában kialakított épületegyüttes nyújtott. 1936-ban 
103 hadirokkant ápoltak az intézményben. $\mathrm{Az}$ áldatlan körülményekről még az Országgyűlés Képviselőházának ülésén is vitáztak a képviselők.

Az ellenzék álláspontja szerint a Hadirokkant Otthonban a legnagyobb probléma a gyakorlatlanság, a rossz szellem és a hibás intézkedések, döntések sorozata:

„...Mert ott ugyebár találunk egy termet, abol csupa egylábú ember van, találunk egy másik termet, abol csak a törzsük van meg a bösöknek, találunk egy harmadik termet, amely tele van olyan ágyon fekvö reszketôsökkeel, akik 18-20 esztendeje minden tagjukban resqketnek, söt olyan is van közöttük, akinek a nyaka reszket, úgyhogy táplálni nem tudják, $s$ az ottaniake kénytelenek végignézni, hogyan pusztul el. Ha azonban ebböl a templomból kijövünk, könnybe lábadt szemekekel s keressük, mi volna itt az. orvoslás, az orvoslást abban látjuk, hogy az ilyen félkearú ugyancsak oda utalt hadirokkantakat vegyék ki abból a környezetböl és adjanak nekik tisztességes hadirokkantellátási dijakat, hogy otthon is meg tudjanak élni..." (OGY Képviselöháának 134. ülése).

A háború során, ezekben a körülményekben sajnos nem történt lényeges változás.

\section{A hadirokkant otthonok sorsa \\ a II. Világháború háború befejezésétől a rendszerváltásig}

A 346/1945. M. E. rendelettel megkezdődött a hadigondozás szabályainak mó- dosítása, annak bizonyos - egyre szűkebb - személyi körre történő korlátozása. A megszorítások alapvetően kétirányúak voltak: egyrészt kizártak a hadigondozásból egyes, az 1944. október 15-ét követően igényjogosulttá vált személyeket, másrészt a hadigondozottak pénzellátásra való jogosultságát a megélhetést biztosító jövedelem vagy tevékenység hiányához kötötték. A fenti jogszabályok az igényjogosultak osztályba sorolását is többször módosították, amely a hadirokkant otthoni jogosultságot is érintette (2/1998. (II. 4.) $\mathrm{AB}$ határozat).

1945. decemberében az utcán kolduló láb és karnélküli hadirokkantak nyomasztóan nagy száma már olyan súlyos társadalmi problémát jelentett, hogy a népjóléti tárca egy hivatalos közleményt adott ki. A közleményben ígéretet tettek ,egy nagy befogadású állami hadirokekant kórbáz. és otthon" kialakítására (MTI/ 5. kiadás, 1945). Ez az ígéret azonban ebben a formában soha nem valósult meg. 1946-tól a Magyar Állami Hadirokkant Otthonban (Bp. II., Marcibányi tér 3.) helyezték el az igényjogosult hadirokkantakat, sajnos a pontos létszámadatok nem ismeretesek.

$\mathrm{Az}$ állami rokkantotthonokban elhelyezett személyek létszáma 1948-ban 200 fö, 1949. évben már 420 fô volt. 1949-tôl a hadigondozottak sorsa „megpecsételődött”, amelyet egy hadigondozásról szóló tájékoztató ekként foglalt össze. A kiadvány „Öszinte előszó” bevezetője nyers egyszerűséggel fogalmazta meg, hogy a kommunista hatalom miként vélekedett a hadigondozottakról: 
„Lássunk tisztán: az elmúlt két világháború rokkantjai botcsinálta bösök voltak, a magyar katonák százezrei a német nagytökések, a magyar nagytókések érdekeiért rokkantak meg vagy pusztultak el s igy csupán sajnálatos áldozatai egy rothadt rendszernek. Ez a rendszer nálunk már a múlté. Ma a nép van a kormányrúdnál, és ha okosan tekint a jövöbe és tiszta szemmel néz a múltba, megad minden lehetö támogatást a háború áldozatainak, de nem részesitheti túlzott elönyökben az igazi bösök, a béke védöi, a munka bösei rovására..." (Hadigondozás, 1948).

A helyzet árnyalása céljából idéznénk a magyar agrárpárt, a Nemzeti Parasztpárt egyik képviselőjének egy 1948-as országgyűlési felszólalásában kifejtett sajátos elképzelését is:

„Gondoskodni kell a rokekantaknak, a koldusoknak és a cigányoknak olyképpen való elhelyezéséröl is, amint azt én 1947 augusztusában Jugoszláviában láttam. Néhány napra kimentem, széjjelnéztem és az ragadta meg elsösorban a figyelmemet, hogy sem egy hadirokkantat, sem egy árvát, sem egy koldust, sem egy cigányt, nem láttam egyik városban sem."

A képviselő mentségére szolgál, hogy elhitte a népjóléti miniszter azon ígéretét, mely szerint a „célcsoport” elhelyezése céljából 150 szeretetotthon építését tervezi a kormányzat, de mai szemmel teljesen elfogadhatatlan és durván kirekesztő ez az elképzelés (Országgyúlési napló, 1947. III. kötet).
A fentiek tükrében kész csoda, hogy 1950-ben a hadirokkant-otthoni elhelyezésre jogosultak (480 fö) részére Budapesten, XII., Németvölgyi-út 41-45. sz. alatt 160, VIII., Horánszky u. 24. sz. alatt 40, Kálmáncsán (Somogy vármegye) 100, Tompán (Bács-Bodrog vármegye) 120, es Putnokon (Borsod vármegye) 60 férôhelyes hadirokkantotthont létesítettek. A hadirokkantotthonokban csak azokat a hadirokkantakat helyezték el, akiknek létfenntartását, külön ápolását és gondozását súlyosabb fogyatkozása miatt sem maga, sem környezete nem tudta biztosítani (Állami költségvetés, 1950). Jogtörténeti érdekesség, hogy katonai hatósági engedély nélkül nem nősülhettek a dualizmus idején - illetve a Nagy Háború után - a „,katonai rokkantház tagjai".

Ezt a korlátozást Rákosiék ugyan nem vették át, azonban ennél egy sokkal félelmetesebb és embertelenebb intézményt vezettek be - szerencsére csak pár évre a Belügyminisztérium felügyeletébe került hadirokkant otthonokban. A katonai rokkantházakban elhelyezett volt katonák, valamennyi bűncselekmény elkövetése esetén (!) a katonai bíráskodás hatálya alá tartoztak. Véleményünk szerint ez a megfélemlítésnek a korszakban alkalmazott egyik szokásos és szánalmas, de félelmetes eszköze volt. A rendszer még a szinte vegetáló volt katonákat is potenciális ellenfélnek tekintette. A hatalom - néha azért megmutatta, hogy milyen ,nagylelkü”. Egy 1950-es koncepciós perben például a $75 \%$-os hadirokkant Kászonyi András halálos ítéletét az Elnöki Tanács 
kegyelemből életfogytiglanig tartó börtönre változtatta, társait azonban halálra ítélte (Hadtörténelmi Levéltár, 1991).

A fentiek alapján egyértelművé vált, hogy a hadirokkant otthonokban elhelyezett katonák, nemhogy ,zongorateremre, közösségi fürdőre", de még kényelmes és otthonszerű ellátásra is alig számíthattak. Korlátozott rehabilitációjukra az állam alig költött és olyan szakemberek sem voltak, akik ebben segíteni tudtak volna.

1951-ben államosították a budapesti Állami Hadirokkant Otthon intézményt. A korábbi korszerű tervvel - amely a hadirokkantak integrációját célozta meg - ellentétben az intézmény csupán ápolást és gondozást nyújtott. Az intézménybe egyre több különböző betegségben szenvedő rászoruló embert helyeztek el, azonban megfelelő képesítésű szakszemélyzet szinte egyáltalán nem állt rendelkezésre.

A hadirokkant otthonba való elhelyezést a 6/1960. (Eü. K . 3.) Eü. M. sz. utasítás szabályozta. A budapesti intézményben 1966-ra a zsúfoltság megszűnt, az itt élők elkerültek a számukra speciálisan kialakított, szegregált szakintézményekbe, s eközben az addig a IV. kerületben élő mozgássérült lányok 1958-ban alapított Állami Szociális Otthona költözött a Marczibányi téri ingatlanba. 1959-ben még 120 hadirokkant élt a részükre épített elkülönített épületszárnyban.

Ebben az évben a hadirokkantak bejelentése alapján a II. kerületi Népi Ellenőrzési Bizottság és az Egészségügyi Minisztérium szociálpolitikai osztálya is vizsgálta az intézményben kialakult állapotokat.
Megállapították, hogy az élelmezés és a tisztaság nem megfelelő színvonalú, de a legnagyobb probléma az, hogy lelketlenül bánnak a gondozottakkal. Az intézmény vezetése ugyanis megfélemlítéssel, „,spicliszolgálat" kiépítésével tartotta sakkban a hadirokkantakat. A vizsgálat során felkérték az Országos Ideg- és Elmegyógyintézet osztályvezető főorvosát, hogy szakmailag értékelje a kialakult helyzetet. Szakvéleménye szerint (Balla, 1959):

„Orvosi szempontból a hadirokkeantakat betegnek kell tekintenünk. Testi fogyatékosságuk eltorzítja szellemi képességeiket, lelki világukat, személyiségüket. Fokorottabb törödést, gondoskodást igényelnek s lelki egyensúlyuk fenntartásáboz szükeség van szervezett kulturális életre, képességeiknek megfelelo" foglalkozásra és olyan kööosségi szellem kialakitására, amely megóvja öket a kétségbeeséstöl, a zülléstöl.".

Sajnos nincs forrásunk arról, hogy miként oldódott meg a hadirokkantak további sorsa, de az egyértelmű, hogy a túlzsúfoltság miatt az elhelyezési körülmények teljesen alkalmatlanok voltak a hadirokkantak méltó ellátására. 1971-től Állami Szociális Intézet néven múködött tovább az intézmény, ahol már nem gondoskodtak a hadirokkantakról, mivel „szétosztották” őket a szociális rendszer egyéb intézményeiben.

Hadirokkantak Otthonába ugyanis csak azt a legalább $75 \%$-os hadirokkantat lehetett beutalni, aki fogyatkozása vagy kora miatt nem volt képes magáról gondoskodni, tartásra kötelezett hozzátartozója 
nem volt, vagy az a gondozását szociális körülményeinél fogva családja körében nem tudták biztosítani (Heinz, 1966).

A vidéken működő Putnoki Hadirokkant Otthon életéről leginkább a helyi megyei lap, az Északmagyarország cikkeiből kaphatunk betekintést. A budapesti hadirokkant otthontól eltérően, a Serényi grófok putnoki „fehér kastélyában” sokkal jobbak voltak az elhelyezési és az életkörülmények. Az újság munkatársai az 1950-es évek közepétől rendszeresen látogatták a volt katonákat. Egyik beszámolójuk szerint:

„... végig jártuk a tişta, meleg hálótermeket, az ebédlöt, a mosdókat s elidōztünk a társalgóteremben, abol sakekoztak, biliárdoztak az otthon gondozottjai."

1957-ben 72 hadirokkant élt az intézetben. Az állam az 1960-as évektől évente több mint egymillió forintot fordított az otthon fenntartására, ruhával, teljes ellátással, zsebpénzzel gondoskodva a lakókról. A gondozottak erejükhöz mérten részt vettek a munkában is. A kastélyt körülölelő közel 10 holdas hatalmas parkon túl kis kertészetet, gazdaságot létesítettek, ahol kora tavasztól késő őszig dolgozgattak, ki-ki megfogyatkozott erejéhez képest. Még saját sertés hízlaldájuk is volt. Az óriási parkból betakarított szénát nem adták el, hanem abból teheneket tartottak és ezzel fedezték a rokkant katonák napi tejszükségletét. Munkájuk után külön jutalom is járt, mert erre is volt „,keret”, évente mintegy 12 ezer forint. Igaz, ez nem volt olyan sok, de ha hozzátették még a zsebpénzt is, akkor rendszeresen kitelt belőle a cigaretta és naponta egy-egy - engedélyezett - ebéd utáni kisfröccs is. Az otthonnak volt „televíziós készüléke”, könyvet ládaszámra kaptak a járási könyvtárból, valamint rádió, biliárd, dominó és kártya is a gondozottak rendelkezésére állt (Adamovics, 1956, Bíró, 1956, 1961).

Az 1950-es évek elején a hadigondozott otthon a proletár internacionalizmus keretében nemzetközivé vált. A hazájukból elmenekült görög kommunisták menekülttáboraként is használták, de a harcokban megsérült görög „hadirokkantak” is elhelyezést kaptak az otthonban. Ez az idilli állapot az 1960-as évek végéig tartott, mivel - az egyre rosszabb állapotú - a kastélyba először 80, majd később 70 fiatal szellemi fogyatékos férfit költöztettek. Ezt követően az intézmény koedukálttá vált és már fiatal értelmi fogyatékos lányokat is befogadtak, egészen az intézmény 1991-es bezárásáig. A „profilváltás” következményeként a még élő hadirokkantakat áthelyezték a még múködő „vidéki hadirokkant otthonokba".

Az áthelyezéssel a putnoki hadirokkantak további sorsa nehezen kutatható mivel kikerültek az állami rendszerből és a helyi tanácsok kezelése alatt lévő szociális otthonokba kerültek.

A hadigondozási iratok esetében a helyi tanácsok iratkezelési munkáját meghatározó 8/1973. MTTH utasítást eltérően értelmezték a különböző típusú tanácsok. Például a főváros és a megyei jogú városok tíz év után selejtezhetőnek ítélték eze- 
ket a dokumentumokat. A 2/1984 MT'TH utasítás pedig továbbra is meghagyta ezt a kutatást nagyban megnehezítő értékelést (Balázs, 2016). Az elkövetkező években, sőt évtizedekben sajnos sok hadirokkant kényszerült koldulással kiegészíteni szerény juttatását, amelyről - meglepően még néhány megyei lap is beszámolt. Említést érdemel például egy név és monogram nélküli pár soros cikk, amelyben a pécsi Széchenyi Gimnázium előtt üldögélő vak hadirokkantnak pár forintot adó és társai által jótékonyságáért kinevetett fiatal fiú emberséges tettét és kiállását örökítette meg a szerző (Dunántúli Napló, 1983).

A hadirokkantak sorsa, otthonszerü elhelyezésük azonban már egyáltalán nem foglalkoztatta a döntéshozókat. A pártállam ellenben nem feledkezett meg a Tanácsköztársaság, a II. világháború kommunista partizánjai, ellenállói és az 1956os forradalom eltipróinak és az arra érdemes párttagok „rokkantházi elhelyezéséről”. Az 1960-as évektől pénzt és energiát nem kímélve kiépítette saját rokkantházi rendszerét, amelyek „elit” szociális otthonok, nyugdíjasházak és veteránotthonok voltak.

Még 1985-ben (!) is létesítettek egy 33 lakrészes veteránotthont Budapest egyik legszebb fekvésű helyén, a Római parton. A megüresedő helyekre, a kialakult gyakorlatnak megfelelően „a Szocialista Hazáért Érdemrenddel kitüntetett elvtársak és özvegyeik" nyertek felvételt és sokak vágyálma volt a korszak egyik legfelkapottabb otthona: a budapesti Rózsa Ferenc Veterán Otthon is. Az otthon emelt szin- tű étkezési normával, kiemelt egészségügyi ellátással és téli-nyári üdüléssel várta az arra jogosult lakókat.

A jó körülmények ellenére a lakók egy része erősen italozott, egyesek a más, kiemelt szociális otthonból (például: Március 21. Otthon) érkező új lakókat „szegényháziaknak" nevezték, amelyet a Budapesti Pártvégrehajtó Bizottság 1973. július 6-án tartott vizsgálata is kiemelt (HU BFL - XXXV.1.a.4.,1973). Természetesen ezekbe az otthonokba a II. világháború „egyszerü” hadirokkantjai nem kaptak elhelyezést. Megdöbbentő és mélyen elgondolkodtató adat, hogy a hetvenes évek derekától egészen a nyolcvanas évek közepéig a régi párttagok otthonainak felépítése ,annyi pénzt emésztett fel, mint a szociális otthonok teljes hálózata” (Horváth. 2012).

\section{Következtetések}

A rokkant katonák a háború és a béke történetének rendkívül elhanyagolt alakjai, így a történetüket és az elhelyezésükre szolgáló intézményeket feldolgozó átfogó nemzetközi és hazai tanulmány sajnos szinte alig létezik. Erre tett kísérletet David A. Gerber - posztmodern amerikai hősökkel (is) foglalkozó kiváló történész az általa szerkesztett: „Finding Disabled Veterans in History" című tanulmánykötetben, amely a nagy nyugati társadalmak veteránjait mutatja be. Gerber szerint a fogyatékossággal élő veteránok a Nagy Háború idején kerültek a társadalmi érdeklődés középpontjába, majd a háborút követően pedig - függetlenül attól, hogy 
az állam a nyertesek vagy a vesztesek oldalán állt - akaratukon kívül váltak szinte megoldhatatlan társadalmi kérdéssé, kezelendő „problémává” (Gerber, 2012). Ezt támasztja alá, hogy az I. világháborúban elesett magyar katonák, özvegyeik, árváik, továbbá „a csonkított, béna és belbetegségben" szenvedő katonákról történő gondoskodás, a mai értelemben vett hadigondozás az első világháborúban került a közérdeklődés látókörébe és a II. világháború után - a rendszerváltásig - szinte eltűnt a köztudatból.

A rendszerváltást követően, az újjáalakult hadirokkant társadalmi szervezetek megpróbálták napirenden tartani a honvéd rokkantotthonok ügyét. Álláspontjuk szerint szükség volt erre az elhelyezési formára, azonban ez később teljesen lekerült a napirendről (Országgyúlés HB, 1991). Ennek a legfőbb oka az volt, hogy a döntéshozók a szociális ellátó rendszer intézményeit látták alkalmasabbnak - az otthonszerű elhelyezést biztosító hadirokkant otthonnál - a magatehetetlen hadirokkantak elhelyezésére. Ezért a II. világháború agg harcosainál fiatalabb generáció, az 1956-os forradalom fegyveres harcaiban részt vevő forradalmárok „otthonszerű elhelyezése" került a figyelem középpontjába.

Az 1993. július 16-án átadott 500 millió forintból felújított mátyásföldi Bajtársak Otthonának egyik épületében 98 lakást alakítottak ki. Egy másik épületben 107, önmagát ellátni képtelen 1956-os forradalmárt helyeztek el, a harmadik épületben pedig irodák kerültek kialakításra. A szociális célra létrehozott épületekben társalgót, konyhát és étkezőt, valamint orvosi rendelőt is kialakítottak (Ferenci, 1993). A Bajtársak Otthona bár nem hadirokkant otthon, de szellemiségében az 1848/49-es agg honvédek menházának, a Pesti Honvéd Menháznak a szellemi utódjának tekinthető.

\section{Irodalom}

Az. Alkotmánybiróság jogszabály alkotmányellenességének utólagos megállapitása és megsemmisitése, valamint mulasztásban megnyilvánuló alkotmánysértés megszüntetése iránt elöterjesztett indítványok, továbbá alkeotmányjogi panaszok tárgyában bozott 2/1998. (II. 4.) AB határozata

Allami költségvetés az 1950. évre, Szociális és Kulturális célok, 1. fejezet Népjóléti Minisztérium 82.

Adamovics I. (1956): A háború áldozatai között, Északmagyarország, február 11. Szombat, 4.

Balázs G. (2016): A változó őrzési idejű iratok problémája a közlevéltárak gyüjtőterületi munkájában, Levéltári Szemle 66. évf. 2. sz. Letöltés: 2019.05.01. Web: https://epa.oszk.hu/03000/ 03048/00002/pdf/21-22.

Balla Ö. (1959): Panasz, védekezés, vizsgálat, szakvélemény - Mi az igazság a Marcibányi téri hadirokkant-otthon ápoltjainak panasza ügyében? Népszava, szeptember 9. 211. szám

Bíró P. (1956): Ország világ megnézheti, Északmagyarország, június 27. Csütörtök, 3 . 
Bíró P. (1961): A putnoki fehérkastély lakói, Északmagyarország január 8. Vasárnap, 3.

Gerber, D. A. (2012): Disabled Veterans in History, University of Michigan Press; Enlarged and Revised Edition edition (6 Jun. 2012)

Fekete G. (1931): Adatok az álizületképződés megelőzéséhez és gyógykezeléséhez, Budapesti Orvosi Újság, XXIX. évfolyam, Budapest, november 26., 48. szám 1.

Ferenci Z. (1993): Bajtársi otthon Mátyásföldön, Helyi Hirek (független folyóirat) 5. évfolyam 7. szám 3.

Hadigondozás (1948). - Gyakorlati tudnivalók a hadigondozási ellátást igénylők, a hadigondozottak és a hadigondozással foglalkozó társadalmi szervek részére, Kiadja a Magyar Hadigondozottak Szövetsége (M. H. SZ.) Tájékoztatási Osztálya, Budapest

Hadtörténelmi Levéltár katonai igazságügyi szerveinek, iratainak repertóriuma 1802 1991 Kiadja Hadtörténelmi Levéltár, Budapest. Letöltés: 2019. május 1. Web: http://mek.oszk.hu/01400/ 01471/01471.pdf 66-68.

Heinz Ervin (1966): A szociális intézetek és gondorottaik helyzete, A Központi Statisztikai Hivatal Népességtudományi Kutató Csoportjának és a Magyar Tudományos Akadémia Demográfiai Bizottságának Kiadványai 11. 106.

Horváth S. (2012): Két emelet boldogság. Mindennapi szociálpolitika Budapesten a Kádár-korban, Napvilág Kiadó, Budapest, 217.
Jegyzőkönyv: az Orsqággyülés honvédelmi bizottságának 1991. május 15-én, szerdán, 13 órakor a Parlament föemelet 66. squámú termében megtartott üléséröl, 1. Napirend: $A$ hadirokkantak szövetsége vezetöinek beszámolója, Országgyúlési Könyvtár, 32.

Klebelsberg K. (1916): A magyar rokekantügy sqervezete. Bíró Miklós könyvnyomdai műintézete, Budapest. Letöltés: 2019. május 1. Web: http://mtda portal.extra.hu/books/klebelsberg_ku no_a_magyar_rokkantugy.pdf 16 .

Mihók S. (2018): A Pesti Invalidus Ház története, Honvédségi Szemle 146. évfolyam 2018/5. szám 128-139.

A népjóléti minisztérium nyilatkozata a hadirokekantakról: Magyar Távirati Iroda (MTI) 5. kiadás, 1945. december 6. 9 óra 10 perc

Az országgyúlés képviselōházának 134. ülése 1936. május 25-én, hétfőn, Országgyülési Könyvtár 132.

Országgyülési napló, 1947. III. kötet, 1948. február 16. - 1948. március 5., Az országgyűlés 48. ülése 1948. év február hó 18-án, szerdán, Országgyúlési Könyvtár 272.

Parádi Jenő (1939): Hadigondozás, hadigondozottak és tűzharcosok érdekvédelme In. Martonffy Károly (szerk.): $A$ mai magyar szociálpolitika - az 1939. évi körigazgatási továbbképzó tanfolyam elöadásai, Keresztes-Fischer Ferenc, Budapest 294.

Pettkó-Szandtner A. (1924): A magyar hadigondozás - visszapillantás és tájékoztató, Pesti Könyvnyomda Részvénytársaság, Budapest 
A Rózsa Ferenc Veterán Otthonban végzett viæssaálatról, MSZMP Budapesti Végrehajtó Bizottságának ülései (HU BFL XXXV.1.a.4.) Budapest Fóváros Levéltára 1973.
Simon K. (2012): Az Óbudai Irgalom Háza történetének vázlata, Tanulmányok Budapest múltjából 2012. 37. szám. Letöltés: 2019.05.01. Web: https:// epa.oszk.hu/02100/02120/00037/pdf 193. 